\title{
Procesy przedsiębiorczości i innowacyjności jako podstawa odnowy organizacyjnej*
}

\section{Entrepreneurship and innovativeness processes as antecedents of organizational renewal}

\author{
Wojciech Dyduch \\ Uniwersytet Ekonomicznyw Katowicach,e-mail: wojciech.dyduch@ue.katowice.pl
}

\begin{abstract}
Streszczenie
Organizacje, poprzez poszukiwanie, rozpoznawanie i podejmowanie szans, podejmują działania bądź dostosowawcze, bądź wyprzedzające, zmieniając w rezultacie elementy strategii lub model biznesu. W kontekście rozpoznawania wyjątkowych zdarzeń prowadzących do odnowy istotnego znaczenia nabierają procesy innowacyjności i przedsiębiorczości organizacyjnej. W artykule przedstawiono te koncepcyjne podstawy przedsiębiorczości, które odnoszą się do inicjowania procesów odnowy w organizacjach poprzez poszukiwanie szans i uruchamianie nowych biznesów. Zwrócono uwagę na potrzebę włączenia przedsiębiorczości w strategię organizacji w celu skutecznej zmiany formuły działania. Ten tok rozumowania stał się inspiracją do zaproponowania macierzy odnowy przedsiębiorczej. W artykule nakreślono jej szkic koncepcyjny, a także przedstawiono wyniki badań empirycznych organizacji w Polsce, dotyczących sposobu i trybu poszukiwania oraz wdrażania przedsiębiorczych szans jako podstawy odnowy organizacyjnej.
\end{abstract}

Słowa kluczowe: odnowa organizacyjna, przedsiębiorczość organizacyjna.

\begin{abstract}
Turbulent and complex environment forces organizations to change the formula in which they run their business. In order to survive and stay on the competitive edge, organizations, by seeking, identifying, taking up and exploiting opportunities either adapt to new conditions, or proactively anticipate and pioneer new solutions, consequently changing strategies or business models. This paper presents the concepts of innovativeness and entrepreneurship, which - through direct relations with opportunity exploitation - act as antecedents of strategic and organizational renewal. Special attention has been drawn at including entrepreneurship and innovativeness processes into organizational strategy, aiming at successful renewal. Different approaches towards identifying and exploiting opportunities, as well as various methods of new business planning became an inspiration for presenting the entrepreneurial renewal matrix. Theoretical aspects were described, as well as results of empirical research concerning entrepreneurial renewal were presented.
\end{abstract}

Keywords: organizational renewal, organizational entrepreneurship.

* Artykuł jest wynikiem badań finansowanych przez Narodowe Centrum Nauki w ramach projektu pt. „Twórczość i przedsiębiorczość w organizacjach" (2011/01/B/HS4/01075). 


\section{Wstęp: teoretyczne podstawy przedsiębiorczości organizacyjnej w procesach odnowy}

Współcześnie nie ma obowiązującej definicji odnowy organizacyjnej [Gabryś 2014], choć przyjmuje się, że jest to przekształcanie lub wymiana tych cech organizacyjnych, które mają wpływ na jej funkcjonowanie w długim okresie [Bełz 2012]. Odnowa organizacyjna pojmowana jest też jako zmiana formuły działania organizacji, owocująca rekonstrukcją modelu biznesu organizacji [Cyfert 2014]. W tym procesie, w wymiarze strategicznym, kadra zarządzająca dokonuje wyboru między procesami dopasowania (adaptacji), doskonalenia, strategicznego zwrotu czy rewitalizacji [Banaszyk, Cyfert 2007]. Przyjmując, że w procesach tych wychodzi się poza istniejące wewnętrzne uwarunkowania organizacji, można założyć, że odnowa organizacji w dużej mierze opierać się będzie na poszukiwaniu szans $\mathrm{w}$ otoczeniu, co stanowi istotę przedsiębiorczości. Z przeprowadzonych kilka lat temu badań jasno wynika, że co druga organizacja w Polsce opiera swój rozwój nie na strategii, lecz na wykorzystaniu okazji [Krzakiewicz, Cyfert, Kraśnik 2006].

Przyjmując kryterium charakteru zmian w organizacji, wyróżnia się zmiany dostosowawcze i wyprzedzające [Cyfert, Bełz, Wawrzynek 2014, s. 16]. Odnowa organizacyjna z wykorzystaniem zmian dostosowawczych ogranicza procesy twórczości i stanowi mniejsze obciążenie systemu zarządzania niż ma to miejsce przy zmianach wyprzedzających. Zmiany wyprzedzające związane są z kolei z przewidywaniem procesów zachodzących w otoczeniu. W obu przypadkach organizacja poszukuje nowych rozwiązań, zdarzeń i szans, jednak sposób ich poszukiwania, jak i charakter samych szans mogą się różnić. Ogólnie rzecz biorąc, wyróżnia się dwa rodzaje przedsiębiorczych szans: wywodzące się z tez J. Schumpetera i tez I. Kirznera [Shane, Venkataraman 2000, s. 13-17]. Te pierwsze oparte są na burzeniu stanu równowagi, wymagają pozyskania i zastosowania nowych informacji; dotyczą przełomowych innowacji, są rzadkie i wymagają twórczości, a zatem związane są z procesem tworzenia nowych pomysłów. Te drugie z kolei, mniej innowacyjne i pospolite, utożsamiane są z dążeniem do stanu równowagi i właściwie ograniczają się do procesu odkrywania istniejących idei. Można zatem wywnioskować, że w procesach odnowy organizacyjnej procesy zmiany adaptacyjnej związane będą w większym stopniu z szansami Kirznerowskimi, imitacją rozwiązań wdrożonych w innych organizacjach czy wdrażaniem idei już odkrytych. Z kolei zmiany wyprzedzające będą powiązane z szansami opartymi na nowości, nowatorskich działaniach i tworzeniem nowych, użytecznych, często przełomowych idei opartych na nowych kombinacjach zasobowych.

Skoro istotą przedsiębiorczości jest rozpoznawanie, podejmowanie i wykorzystywanie szans, a te są warunkiem inicjującym procesy odnowy, warto się przyjrzeć założeniom koncepcyjnym przedsiębiorczości organizacyjnej, które owocują zmianą sposobów działania organizacji. Sam postulat mówiący, że procesy przedsiębiorczości - szczególnie wchodzenie w rolę pioniera, innowacyjność i podejmowanie ryzyka - stanowią podstawę odnowy organizacyjnej wraz z odnową rynków, na jakich organizacja działa, jest obecny w literaturze przedmiotu od dłuższego czasu [Miller 1983]. Przedsiębiorczość organizacyjna to proces tworzenia nowych biznesów w istniejących firmach w celu zwiększenia zyskowności i wzmocnienia pozycji konkurencyjnej firmy lub odnowy strategicznej istniejącego modelu biznesu [Zahra 1991]. W innych konceptualizacjach zwraca się uwagę na przedsiębiorczość organizacyjną jako proces rozszerzenia domeny kompetencyjnej organizacji i podejmowanie szans właściwych tym kompetencjom poprzez wewnętrznie tworzone i przygotowywane innowacje [Burgelman 1984, s. 154], które znacznie zmieniają układ sił konkurencyjnych $\mathrm{w}$ sektorze lub tworzą nowe sektory [Ferreira 2002].

Przedsiębiorczość organizacyjna jest to proces odnowy [Sathe 1989] złożony $\mathrm{z}$ powiązanych wymiarów: innowacji i podejmowania ryzyka, wzmacnianych napięciem strategicznym, które doprowadza do tworzenia nowych biznesów poprzez rozwój i komercjalizację innowacji. Drugi wymiar obejmuje procesy odnowy organizacyjnej, które wzmacniają zdolność organizacji do konkurowania i podejmowania ryzyka [Miller 1983]. Odnowa może przyjmować różne postaci, m.in. redefinicję modelu biznesu, reorganizację czy wprowadzanie holistycznych zmian mających na celu pobudzanie innowacyjności.

M. Bratnicki [2008] zaproponował konfiguracyjne ujęcie przedsiębiorczości organizacyjnej, które opiera się na procesach (przygotowywanie innowacji, podejmowaniu ryzyka związanego z uruchamianiem nowych biznesów, odnawianie strategiczne) i na elementach treści (nastawienie umysłu, kultura organizacyjna, definicja powodzenia i domeny działalności, strategiczne zarządzanie zasobami, regeneracja i odmłodzenie). W ujęciu tym sugeruje się jednocześnie, że organizacje, które nabywają zdolności integrowania procesowych atrybutów i składników treści, są w stanie nie tylko odnawiać siebie i swoje strategie, ale też przedsiębiorczo tworzyć nowe wartości i bogactwo.

Współczesne koncepcje uznają innowacyjność za składową przedsiębiorczości organizacyjnej (np. [Miller 1983]). Przyjmując z kolei kryterium sekwencyjności, można postrzegać innowacyjność jako pierwszy etap twórczej strategii, gdzie drugim jest przedsiębiorczość rozumiana jako komercjalizacja innowacyjnego pomysłu. Sekwencja ta wspierana jest przez odpowiednie struktury organizacyjne oraz przywództwo [Dyduch 2013].

Literatura dotycząca zarządzania strategicznego wyróżnia trzy typy przedsiębiorczości organizacyjnej [Stopford, Baden-Fuller 1994]. Pierwszy z nich to intraprzedsiębiorczość, rozumiana jako tworzenie nowych biznesów wewnątrz istniejącej organizacji. Drugi polega na nowej kombinacji zasobów, która burzy ustaloną równowagę i powoduje zmianę reguł gry w sektorze poprzez wdrażanie przełomowych innowacji (podejście Schumpeterowskie). Trzeci typ przedsiębiorczości polega na transformacji, czyli odnowie istniejących firm. Przedsiębiorczość jest zatem różnie pojmowana, a innowacyjność może być traktowana jako zachowanie przedsiębiorcze, wspierające odnowę, jak i jako rutyna organizacyjna występująca $\mathrm{w}$ firmach przedsiębiorczych [Stevenson, Jarillo 1990]. Bez względu na przyjęty sposób pojmowania przedsiębiorczości, wszystkie jej typy opierają się na innowacyjności, wymagają 
zatem zmian w utrwalonych sposobach wykorzystania zasobów i procesach tworzenia nowych dynamicznych zdolności [Stopford, Baden-Fuller 1994, s. 522].

Zmiana w sposobie wykorzystania zasobów przekształca organizację w nowy twór, co jest wyrazem zachowań przedsiębiorczych. Rozwój nowego biznesu w ramach istniejącej organizacji jest jednym ze sposobów osiągania odnowy, obok mniej radykalnych sposobów w ramach przyjętej strategii, takich jak zorientowanie uruchomionych biznesów na większą konkurencyjność, zmiany $\mathrm{w}$ procesach marketingu i dystrybucji, przekierowanie rozwoju produktu czy zmiany w procesie produkcji [Guth, Ginsberg 1990]. Jednocześnie wyodrębniono i opisano trzy typy firm, w których procesy przedsiębiorczości inicjujące odnowę zależą od działań indywidualnych przedsiębiorców, struktur organizacyjnych, a także podejścia do tworzenia strategii. Są to [Miller 1983]: (a) organizacje proste, małe i scentralizowane, w których procesy odnowy zależą od osobowości przywódcy, (b) organizacje planujące, większe i wykorzystujące formalne procesy planowania i kontroli, w których odnowa dokonuje się poprzez zintegrowanie strategiczne i dopasowanie produktów do rynków, (c) firmy organiczne, dostosowujące się do swojego otoczenia, w których dominuje władza ekspercka i procesy otwartej komunikacji, gdzie za odnowę odpowiedzialne będzie dopasowanie struktur do otoczenia.

Procesy przedsiębiorczości stanowią początek odnowy organizacyjnej. Wskazuje się, że w otoczeniu dynamicznym i rozwijającym się procesy przedsiębiorczości, zakładania nowych firm oraz odnowy są szczególnie widoczne [Zahra 1993]. Zaproponowany i rozwinięty został nawet model zależności między innowacjami produktowymi, rozumianymi jako wykorzystywanie wiedzy łączącej możliwości technologiczne z rynkiem, a odnową organizacyjną [Dougherty 2002]. Potrzeba rozumienia przedsiębiorczości organizacyjnej w kategoriach procesów odnowy wynika z kilku przyczyn [Kuratko, Montagno, Hornsby 1990]: (a) palącej potrzeby zmian, innowacji i ulepszeń w organizacjach w celu uniknięcia stagnacji i upadku, (b) słabości tradycyjnego, mechanistycznego modelu zarządzania, (c) odpływu twórczych pracowników, zniechęconych biurokracją w dużych korporacjach. Odpowiedzią na wskazane potrzeby są z pewnością procesy przedsiębiorczości organizacyjnej, jednak będą one skutecznie inicjowały odnowę organizacyjną (jedynie) pod warunkiem włączenia ich w strategię organizacji.

\section{Przedsiębiorczość i innowacyjność jako elementy strategii organizacji}

W celu ustawicznej i ciągłej odnowy organizacyjnej, procesy przedsiębiorczości nie mogą działać doraźnie, po wierzchu, czy w sposób nieustrukturyzowany, w separacji od głównego zamierzenia i kierunku strategicznego organizacji. Istotne jest włączenie procesów innowacyjności i przedsiębiorczości do strategii organizacji, tak aby odnowa strategiczna i organizacyjna odbywała się w sposób spójny i skoordynowany z podejmowanymi działaniami i zachowaniami przedsiębiorczymi. W rezultacie rozwija się przedsiębiorczość strategiczną, polegającą - mówiąc najogólniej - na włączaniu organizacyjnych zasobów i zdolności w zgodzie z kierunkiem strategicznym $\mathrm{w}$ proces poszukiwania, podejmowania i wykorzystywania szans znajdujących się w otoczeniu [Bratnicka, Dyduch 2014].

Rolą działań przedsiębiorczych jest zapewnienie żądanej innowacyjności i różnorodności wewnątrz organizacji, co często wymaga niestandardowych działań i eksperymentowania. Wdrażanie strategii z kolei jest oparte na procesach planowania, porządkowania, klasyfikowania czy strukturyzowania. Zadaniem zarządzania strategicznego $\mathrm{w}$ organizacjach przedsiębiorczych jest godzenie sprzeczności między tymi procesami. Badacze odróżniają też strategię przedsiębiorczą (rozumianą jako częsty i ustawiczny wysiłek nakierowany na osiąganie przewagi konkurencyjnej oparte na innowacji) od przedsiębiorczości strategicznej (rozumianej jako zaakceptowane na poziomie strategicznym wdrażanie innowacji polegające na przekształcaniu szans w sprawdzające się w warunkach rynkowych produkty lub usługi) [Miller, Friesen 1982; Bilton, Cummings 2010].

Niedawno zaproponowano model strategicznej przedsiębiorczości organizacyjnej oparty na elementach wejścia-wyjścia [Ireland, Covin, Kuratko 2009]. Na wejściu tego modelu znajdują się czynniki sprzyjające strategicznemu rozwijaniu przedsiębiorczości (np. przedsiębiorczość uczestników organizacji, otoczenie sprzyjające poszukiwaniu szans). Na samą strategię przedsiębiorczości organizacyjnej składają się: przedsiębiorcza wizja strategiczna, architektura organizacyjna wspierająca procesy przedsiębiorczości i zachowania przedsiębiorcze. Na wyjściu modelu znajdują się rezultaty wdrożenia działań przedsiębiorczych obejmujące wyższą efektywność, ponowne zdefiniowanie strategii oraz rozwój zdolności dynamicznych.

Jako wzbogacenie tej konceptualizacji Hitt, Ireland, Sirmon i Trahms [2011] również rozwinęli model przedsiębiorczości strategicznej oparty na elementach wejścia i wyjścia. Wskazuje on trzy zasadnicze elementy procesu przedsiębiorczości strategicznej: a) zasoby i czynniki na wejściu wraz z uwarunkowaniami otoczenia, b) procesy orkiestracji zasobów oraz c) wyniki. Do pierwszej grupy należy otoczenie, jego zasobność, dynamizm i wzajemne powiązania, zasoby organizacyjne przedsiębiorcza kultura i przywództwo, zasoby indywidualne - przedsiębiorcze nastawienie umysłu i umiejętności społeczne. W wyniku orkiestracji zasobów tworzona jest wartość dla klienta i bogactwo. Rezultatami procesów przedsiębiorczości są korzyści indywidualne, społeczne i (oczywiście) organizacyjne, w postaci m.in. właśnie odnowy, innowacji, nowej wiedzy i technologii.

Odnowa organizacyjna jest rezultatem właściwego rozpoznania i wdrożenia szans oraz efektywnego przekształcenia innowacji na sprawdzający się $\mathrm{w}$ warunkach rynkowych pomysł lub usługę. Proces ten składa się z sześciu faz [Bilton, Cummings 2010, s. 112]: (a) fazy rozpoznania, polegającej na uświadomieniu sobie, że dany pomysł ma potencjał; (b) fazy rozwoju, polegającej na przygotowaniu do przekształcenia pomysłu w potencjalny produkt lub usługę; (c) fazy oceny, która ma dać ostateczną odpowiedź, czy innowację warto wprowadzić na rynek, (d) właściwej fazy opracowania, która wymaga pracy i pilności, (e) fazy wdrożenia produktu na rynek, (f) fazy odnowy i osiągania innych rezultatów. 


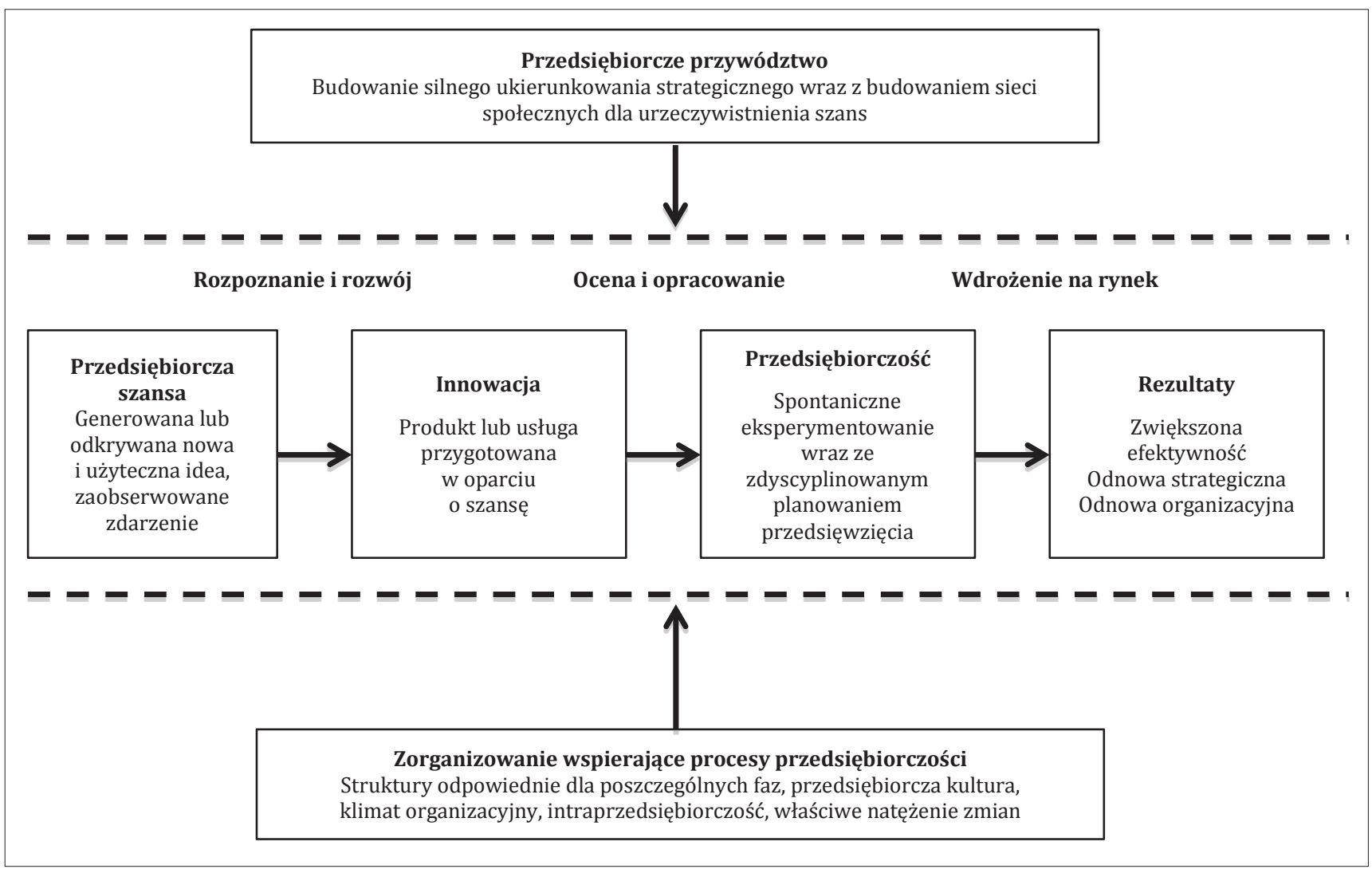

Rysunek 1. Procesy innowacyjności i przedsiębiorczości sprzyjające odnowie organizacyjnej

Źródło: opracowanie własne.

Można założyć, że procesy przedsiębiorczości sprzyjające odnowie organizacyjnej są charakteryzowane przez następujące zachowania i działania uczestników organizacji: (a) podejmowanie nowatorskich działań na zasadzie eksperymentowania bez względu na brak pełnej analizy i całkowitej wiedzy w celu wykorzystania nadarzających się okazji, (b) staranne i konsekwentne wdrażanie nowych idei mimo związanej z tym ciężkiej pracy, (c) obserwowanie i analizowanie idei oraz zdarzeń pod kątem potencjalnych powiązań pomiędzy innowacją a rynkiem, (d) rozwijanie rozpoznanych szans pod warunkiem cenności strategicznej idei i projektów, czyli zgodności ze stylem zarządzania organizacją, możliwości zawłaszczania wytworzonej wartości, trudności w substytucji i naśladowaniu, możliwości organizacyjnego wsparcia, (e) staranne planowanie szczegółów skutecznego i ekonomicznego wykorzystania pozytywnie ocenionych szans, (f) uruchamianie nowych przedsięwzięć w sposób zdyscyplinowany, z dbałością o szczegóły. Całość wspomagana jest właściwym zorganizowaniem i przedsiębiorczym przywództwem (rys. 1).

Uczestnicy organizacji proaktywnie rozpoznający niecodzienne szanse i zdarzenia określani są jako ludzie, którzy w sposób niestandardowy, niezobowiązujący i mało sformalizowany poszukują interesujących pomysłów, co zdarza się w fazie rozpoznania. Poszukują szans i odkrywają potrzeby rynku poprzez podróżowanie, sprawdzanie różnych opcji i bawienie się pomysłami. Z drugiej strony to osoby, które muszą wykazać się szczególną uwagą i dbałością o wszystkie elementy procesu wprowadzania nowego produktu, który niesie ze sobą potencjał sprawdzenia się i osiągnięcia rynkowego sukcesu.

Współczesne organizacje funkcjonują w otoczeniu wrogim, dynamicznym i burzliwym. W takim otoczeniu, charakteryzującym się wysokim stopniem nieprzewidywalności i zmienności, należy odwoływać się do rozwiązań organicznych, opartych na uniwersalizacji, decentralizacji i większej elastyczności [Cyfert, Bełz, Wawrzynek 2014]. Sposób zorganizowania jest powiązany zatem z natężeniem elastyczności, swobodą eksperymentowania, oddolnych inicjatyw, wyzwalaniem twórczości i przyzwoleniem na niekonwencjonalne sposoby poszukiwania i rozpoznawania przedsiębiorczych szans. Oparcie projektu organizacji na centralizacji i narzucania jednolitych wartości w całej organizacji, przekładających się na osiągnięcie tego samego celu nadrzędnego, może w małym stopniu sprzyjać poszukiwaniu szans. Z kolei oparcie projektu na autonomii poszczególnych części organizacji, która zapewnia swobodę manewru niezbędną do eksperymentowania i nawiązywania kontaktów społecznych, będzie wsparciem dla realizacji procesów odnowy poprzez efektywne poszukiwanie i wdrażanie przedsiębiorczych szans.

Możliwości odnowy organizacyjnej przez rozwijanie innowacyjności i przedsiębiorczości w wymiarze strategicznym zależą zatem od właściwego zorganizowania, które powinno charakteryzować się kilkoma zasadniczymi właściwościami [Bilton, Cummings 2010, s. 207]: (a) silną kulturą organizacyjną, 
która spaja wnętrze organizacji, pozwalając jej jednocześnie dostosowywać się do zmian w otoczeniu i do wprowadzania nowych pomysłów; (b) odpowiednim klimatem organizacyjnym, w którym rozpoznaje się dobre pomysły bez względu na to, przez jakich uczestników organizacji zostały zgłoszone; w którym ocenia się pomysły merytorycznie i na tej podstawie promuje; (c) otoczeniem sprzyjającym wymianie poglądów między ekspertami i spontanicznymi entuzjastami; (d) wspieraniem procesów intraprzedsiębiorczości, generowaniem pomysłów zarówno przez uczestników organizacji, jak i osoby z zewnątrz; (e) wielokierunkowością i oparciem w większym stopniu na procesach niż zadaniach, co sprzyja szybszemu podejmowaniu decyzji; (f) projektem charakterystycznym dla organizacji obustronnej; z uczeniem się eksploracyjnym i eksploatacyjnym przy zapewnieniu autonomii uczestników organizacji; (g) odpowiednim dawkowaniem wprowadzania zmian; unikaniem zmian dla samej zmiany. Warto też zwrócić uwagę na zaangażowanie wszystkich uczestników organizacji i rozwijanie współpracy między nimi, zachowanie rozsądnego poziomu kontroli strategicznej, a także wdrażanie polityki wynagradzania wspierającej poszukiwanie szans i tworzenie wartości.

\section{Przedsiębiorcza odnowa oparta na elastyczności poszukiwania szans i staranności planowania przedsięwzięć}

W literaturze przedmiotu zakłada się, że w warunkach stabilnego otoczenia organizacje korzystają z własnych zasobów i kompetencji, podejmowanie zaś szans charakterystyczne jest dla organizacji działających w otoczeniu burzliwym, wrogim i dynamicznym. Współcześnie można założyć, że znacząca większość organizacji działa w otoczeniu zmiennym i burzliwym, należy zatem poszukać takiej typologii odnowy, która oprze się na różnych sposobach podejmowania szans przez organizacje, a także weźmie pod uwagę sprzeczne charakterystyki organizacyjne w zakresie wdrażania nowego biznesu. Biorąc jako podstawę teoretyczną koncepcję przedsiębiorczości Biltona i Cummingsa [2010] wraz ze wskazywanymi sprzecznościami (eksperymentowanie kontra staranne i zdyscyplinowane planowanie) oraz dwie formy odnowy według kryterium procesowego (dopasowanie i antycypację), można zaproponować typologię odnowy przedsiębiorczej. Wymiarem na osi odciętych niech będzie odkrywanie istniejących szans i inicjowanie zmian bez względu na pełną wiedzę i dostępne pełne, oparte na racjonalnych danych analizy. W tym wymiarze uczestnicy organizacji, starając się wykorzystywać nadarzające się okazje, podejmują nowatorskie działania na zasadzie eksperymentu, nie zważając na brak pełnej analizy i całkowitej wiedzy. Poszukiwanie szans następuje w sposób amatorski, odkrywanie zaś potrzeb rynku następuje poprzez podróżowanie, sprawdzanie różnych opcji i alternatyw czy bawienie się (tematem). Uczestnicy organizacji rozpatrują jednak idee i zaobserwowane zdarzenia pod kątem potencjalnych powiązań pomiędzy innowacją a rynkiem. Efektem takiego działania w niskim natężeniu może być słabo przygotowana innowacja oparta na olśnieniu, zapale lub fascynacji, jednak bez właściwego wsparcia organizacyjnego może się nie udać. W wysokim natężeniu nowatorskie działania uczestników organizacji przy odpowiednim zaprojektowaniu i wsparciu organizacyjnym mogą owocować przełomowymi innowacjami, burzącymi dotychczasowy stan równowagi, zmieniającymi reguły gry w sektorze.

Wymiarem na osi rzędnych niech będzie staranne, zdyscyplinowane planowanie przedsiębiorczych przedsięwzięć opartych na nadarzających się okazjach. W tym wymiarze uczestnicy organizacji uruchamiają nowe przedsięwzięcia w sposób zdyscyplinowany, dbając o szczegóły wykonania. Rozwijają rozpoznane szanse, biorąc pod uwagę cenność strategiczną zaobserwowanych w organizacji i poza nią idei czy projektów. Zwracają przy tym uwagę na zgodność z zamierzeniem strategicznym organizacji, ze stylem zarządzania organizacją, na problemy zawłaszczenia wytworzonej wartości, stopień trudności w substytucji i naśladowaniu, a także na możliwość wsparcia organizacyjnego. W tym wymiarze następuje ocena zasadności dalszego pójścia w ślad za rozpoznanymi szansami pod kątem wykonalności czy ekonomicznej racjonalności. Niska dyscyplina rozwijania rozpoznanych szans może wywołać brak komercjalizacji, wysoce zdyscyplinowane zaś przygotowanie biznesu oparte na rozpoznanej szansie ma możliwość pozytywnego wdrożenia i wprowadzenia na rynek. Takie podejście usuwa jednak z pola widzenia twórczość w miejsce racjonalności. Staranne planowanie może owocować przygotowaniem mniej przełomowej, mniej radykalnej innowacji, za to takiej, która będzie przyjęta na rynku.

Zestawiając te dwa sprzeczne wymiary (nowatorskie działania oparte na spontaniczności, eksperymentowanie oraz amatorskie działania kontra pilne i staranne przygotowanie przedsięwzięć), można otrzymać macierz przedstawiającą typy przedsiębiorczej odnowy (rys. 2). Niskie natężenie eksperymentowania i niskie natężenie planowania biznesu spowoduje, że szanse przedsiębiorcze bądź nie zostaną w ogóle zauważone i rozpoznane, bądź nie zostaną rozwinięte do postaci produktów czy usług. Taka sytuacja zaowocuje więc brakiem odnowy. Niskie natężenie eksperymentowania i podejmowania nowatorskich działań zestawione z wysokim natężeniem planowania, przygotowywania i uruchamiania biznesu w rezultacie da innowacje w niewielkim stopniu twórcze. Być może będzie to imitacja pomysłów innych organizacji, być może nadążanie za tym, co już na rynku istnieje. Tę sytuacje można więc uznać za formę odnowy, jaką jest dostosowanie się, czyli adaptacja.

Wysokie natężenie eksperymentowania, nowatorskich działań bez względu na posiadaną wiedzę, zestawione z niską racjonalnością wprowadzanego biznesu, może doprowadzić do przypadkowego przełomowego odkrycia. Odnowa w tym polu będzie miała charakter antycypacyjny, wyprzedzający. Wprowadzanie zmian będzie szybkie i nieopóźnione złożonymi procesami przygotowawczymi, inercją organizacyjną czy procedurami biurokratycznymi związanymi z wdrożeniem. Ze względu jednak na brak merytorycznej i ekonomicznej oceny może owocować zarówno nieoczekiwanym sukcesem, jak i niepowodzeniem. Nie jest to zatem odnowa charakterystyczna dla sektora wysokich technologii, z zaangażowaniem kapitału w badania i rozwój czy usługi o dużej wrażliwości ze strony interesariuszy. 


\begin{tabular}{|c|c|c|c|}
\hline & & \multicolumn{2}{|c|}{$\begin{array}{c}\text { Poziom eksperymentowania i spontanicznego podejmowania nowatorskich działań, } \\
\text { bez względu na posiadaną wiedzę i analizy ekonomiczne }\end{array}$} \\
\hline & & Niski & Wysoki \\
\hline \multirow{2}{*}{ 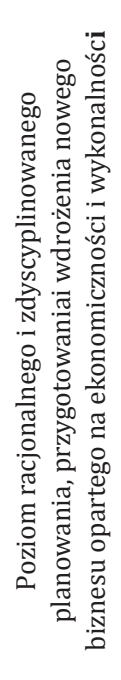 } & $\begin{array}{l}\frac{7 y}{0} \\
0 \\
3 \\
3\end{array}$ & $\begin{array}{l}\qquad \text { Analityk - adaptacja } \\
\text { Ze względu na ograniczenie procesów twórczości } \\
\text { i eksperymentowania, a także skupienie się na } \\
\text { racjonalnym, opartym na ekonomiczności } \\
\text { i wykonalności procesie planowania nowych } \\
\text { biznesów, w efekcie powstają dobrze przygotowane, } \\
\text { acz mało przełomowe innowacje. Zwykle mają } \\
\text { charakter naśladowczy, a celem ich wdrożenia jest } \\
\text { dorównanie kroku konkurencji. }\end{array}$ & $\begin{array}{l}\text { Wysoki poziom efektywności odkrywania szans wraz ze starannym } \\
\text { procesem przygotowania na ich podstawie innowacji oraz skuteczna } \\
\text { komercjalizacja owocują istotnymi, ważnymi, często przełomowymi } \\
\text { innowacjami, zmieniającymi reguły gry w sektorze. W rezultacie może } \\
\text { następować zmiana modelu biznesu czy strategii, rozwój organizacji } \\
\text { poprzez pozyskanie nowych rynków. }\end{array}$ \\
\hline & $\frac{i \vec{y}}{i z}$ & $\begin{array}{l}\text { Stagnacja } \\
\text { Brak odnowy przedsiębiorczej. Niskie natężenie } \\
\text { nieograniczonego racjonalnością eksperymentowania, } \\
\text { spontaniczności wraz z niskim natężeniem dyscypliny } \\
\text { w planowaniu nowego biznesu powoduje, że } \\
\text { organizacja traci konkurencyjność i jest eliminowana } \\
\text { z grona graczy w sektorze. }\end{array}$ & $\begin{array}{l}\qquad \text { Artysta - nieefektywna antycypacja } \\
\text { Odnowa przedsiębiorcza jest możliwa ze względu na trafne wychwytywanie } \\
\text { i rozpoznawanie wyjątkowych zdarzeń i szans w otoczeniu przez } \\
\text { uczestników organizacji. Szybkie wdrażanie tych szans do postaci } \\
\text { sprawdzających się w warunkach rynkowych pomysłów jest możliwe dzięki } \\
\text { eksperymentowaniu z pominięciem inercji organizacyjnej i przekraczaniu } \\
\text { status quo bez względu na ekonomiczną racjonalność. Panuje poczucie } \\
\text { przekształcenia szansy na pomysł, który sprawdzi się na rynku. }\end{array}$ \\
\hline
\end{tabular}

Rysunek 2. Typy przedsiębiorczej odnowy

Źródło: opracowanie własne.

Wysoki poziom nowatorskich działań opartych na eksperymentowaniu, podróżowaniu i obserwowaniu szans i zdarzeń wraz z wysokim poziomem dyscypliny planowania biznesu zaowocuje natomiast pełną przedsiębiorczą odnową. W tym polu obserwowane szanse i zdarzenia będą miały charakter wyprzedzający, nowatorski i przełomowy, a ich wdrożenie ze względu na ocenę merytoryczności, ekonomiczności i wykonalności będzie najbardziej skuteczne. Przedstawiona macierz jest oczywiście jedną z propozycji diagnozy sposobów podejmowania szans w organizacjach i planowania nowych przedsięwzięć prowadzących do odnowy. Oparta została na sprzeczności między oddolnym, dyletanckim eksperymentowaniem w poszukiwaniu i rozpoznawaniu szans a zdyscyplinowanym i skrupulatnym planowaniem nowych przedsięwzięć. W świetle tej propozycji warto przyjrzeć się typom przedsiębiorczej odnowy organizacji w Polsce.

\section{Procesy przedsiębiorczej odnowy organizacyjnej w Polsce}

W celu empirycznego sprawdzenia poziomu wymiarów odnowy przedsiębiorczej zdecydowano się zebrać dane z organizacji za pomocą kwestionariusza ankiet. Dwa wymiary przedsiębiorczej odnowy, a więc amatorskie eksperymentowanie oraz staranne planowanie biznesu, zostały zoperacjonalizowane do postaci zmiennych, których wielkość była oceniana za pomocą stwierdzeń $\mathrm{w}$ kwestionariuszu ankiety. Zadanie respondentów, wywodzących się ze średniego i wyższego szczebla zarządzania, polegało na ocenie każdego stwierdzenia odnoszącego się do zjawiska w badanej organizacji na siedmiopunktowej skali Likerta.

W celu sprawdzenia poziomu wymiarów odnowy przedsiębiorczej w 2012 roku zostały przeprowadzone właściwe bada- nia empiryczne na podstawie danych uzyskanych z 606 organizacji działających na terenie województwa śląskiego. Wybór regionu podyktowany był faktem jego ciągłych przemian z obszaru, na którym niegdyś dominował przemysł ciężki, na obszar związany z usługami, zarządzaniem wiedzą, twórczymi branżami przemysłu i rozwijaniem aglomeracji przedsiębiorczości opartej na szansach. Województwo śląskie, poprzez relatywnie niższą niż w innych regionach atrakcyjność turystyczną, skupia się na bardziej intensywnym poszukiwaniu szans w biznesie. Najwyższa w Polsce gęstość zaludnienia, wysoki wskaźnik urbanizacji, duża liczba konsumentów, dogodne połączenia komunikacyjne a także relatywnie wysoka liczba zakładanych małych i średnich przedsiębiorstw to tylko niektóre $\mathrm{z}$ uwarunkowań powodujących, że wykorzystanie szans, a także przełożenie innowacji na rynek może mieć w na tym obszarze szczególne znaczenie.

Próba badawcza obejmowała 606 organizacji biznesowych, działających w sektorze prywatnym. Spośród nich $50,5 \%$ były to organizacje małe, $16,1 \%$ średnie, a $33,4 \%$ stanowiły organizacje duże. Najwięcej, bo 18,2\% badanych przedsiębiorstw, działało w usługach, 16\% zajmowało się handlem hurtowym i detalicznym, 11,1\% przetwórstwem przemysłowym, 10,7\% budownictwem, 9,7\% zaś działalnością finansową i ubezpieczeniową. Udział pozostałych branż wyniósł poniżej $10 \%$.

Wykorzystując zaproponowaną czteropolową macierz odnowy przedsiębiorczej, zbadano, jakim natężeniem poszczególnych wymiarów charakteryzują się badane organizacje. Mediana we wszystkich przypadkach wyniosła 4, zatem przyjęto, że niskie natężenie danego wymiaru jest reprezentowane przez oceny w kwestionariuszu poniżej tej wartości, natężenie zaś wysokie - powyżej. Bliższa analiza ocen poszczególnych wymiarów przedsiębiorczej odnowy w zależności od zmiennych 
kontrolnych pozwala na uchwycenie drobnych różnic między poszczególnymi grupami organizacji. Jeśli chodzi o wybory w zależności od wieku organizacji, różnice te zostały przedstawione na rys. 3 .

W każdej grupie wiekowej organizacji nieznacznie wyżej ocenione zostało staranne planowanie nowych przedsięwzięć względem amatorskiego podejścia z improwizacją i eksperymentowaniem. Okazuje się, że badane organizacje także niezależnie od wieku kładą nieznacznie większy nacisk na staranne przygotowanie przedsięwzięć (średnia dla wszystkich organizacji 4,37) niż na dyletanctwo (średnia 4,05), a największe różnice $\mathrm{w}$ wyborach skrajnych rozwiązań możliwych $\mathrm{w}$ ramach tego wymiaru widoczne są w organizacjach średnich i dużych.
W rezultacie z przeprowadzonych badań wynika, że tylko organizacje najstarsze znajdują się w pozycji analityka, przedkładając staranne planowanie nad eksperymentowanie. Organizacje najmłodsze, a także organizacje dojrzałe (14-22) charakteryzują się pełną odnową przedsiębiorczą, godząc eksperymentowanie i spontaniczne nowatorskie działania z racjonalnym planowaniem nowych biznesów. Należy jednak zauważyć, że poziom przedsiębiorczej odnowy nie jest wysoki. Na siedmiostopniowej skali uzyskane wartości oscylują w okolicach mediany.

Pewne różnice pojawiły się także $w$ wymiarach przedsiębiorczej odnowy w zależności od rodzaju prowadzonej działalności (rys. 4). Średnia ocena poziomu eksperymentowania we

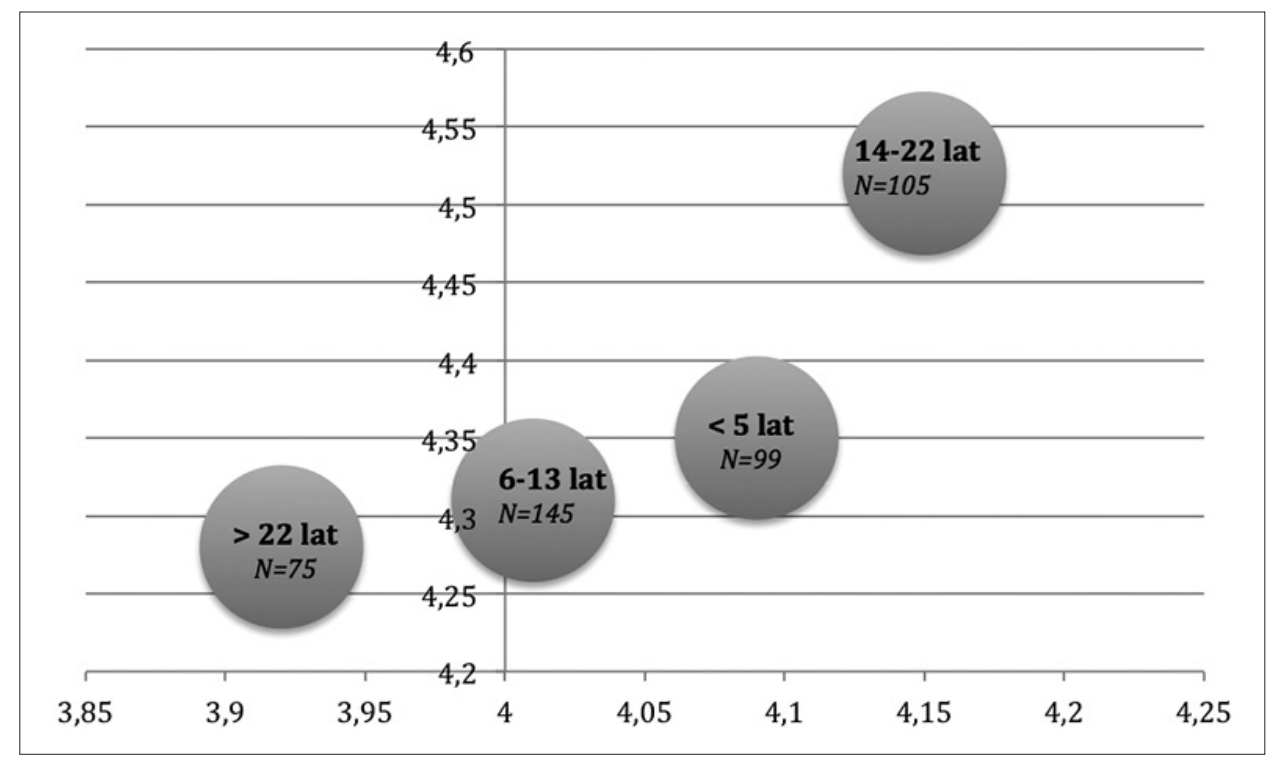

Rysunek 3. Typ przedsiębiorczej odnowy w zależności od okresu istnienia przedsiębiorstw

Źródło: opracowanie własne.

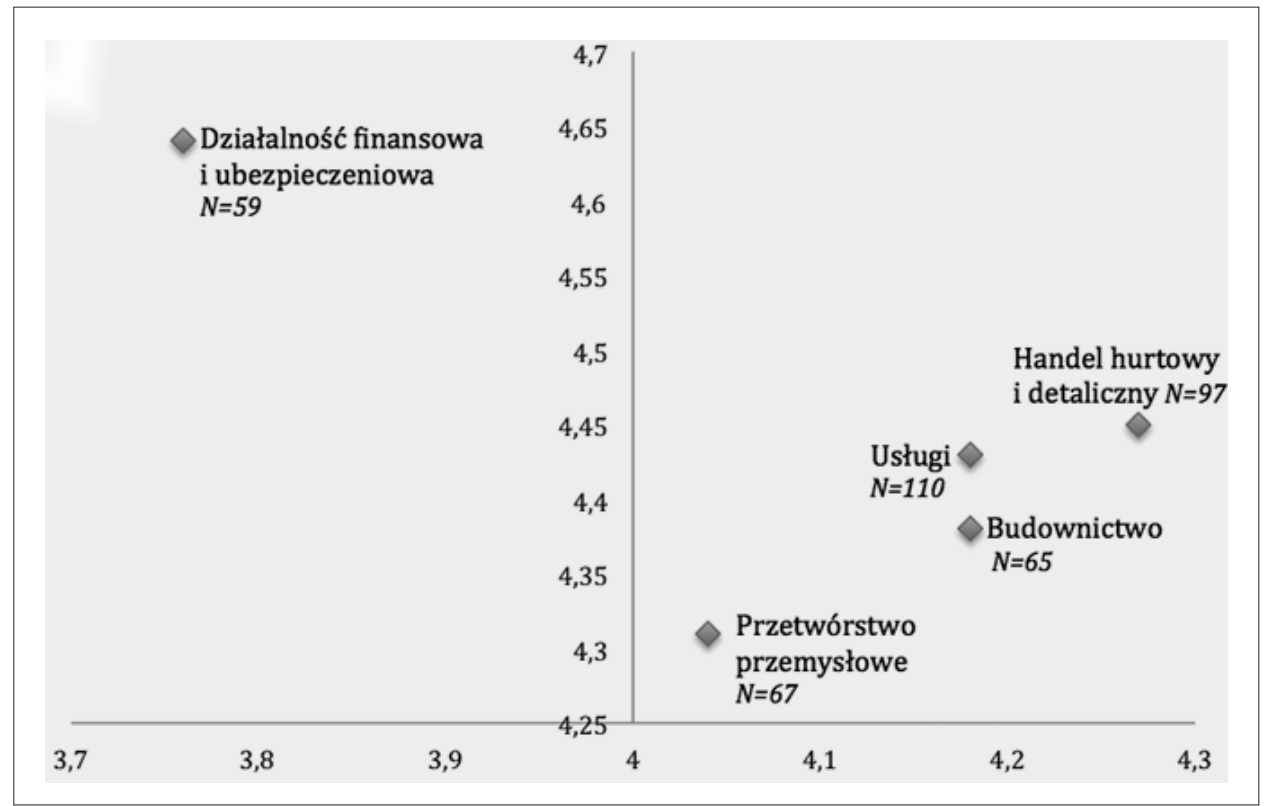

Rysunek 4. Wymiary przedsiębiorczej odnowy a sektor działalności

Źródło: opracowanie własne. 


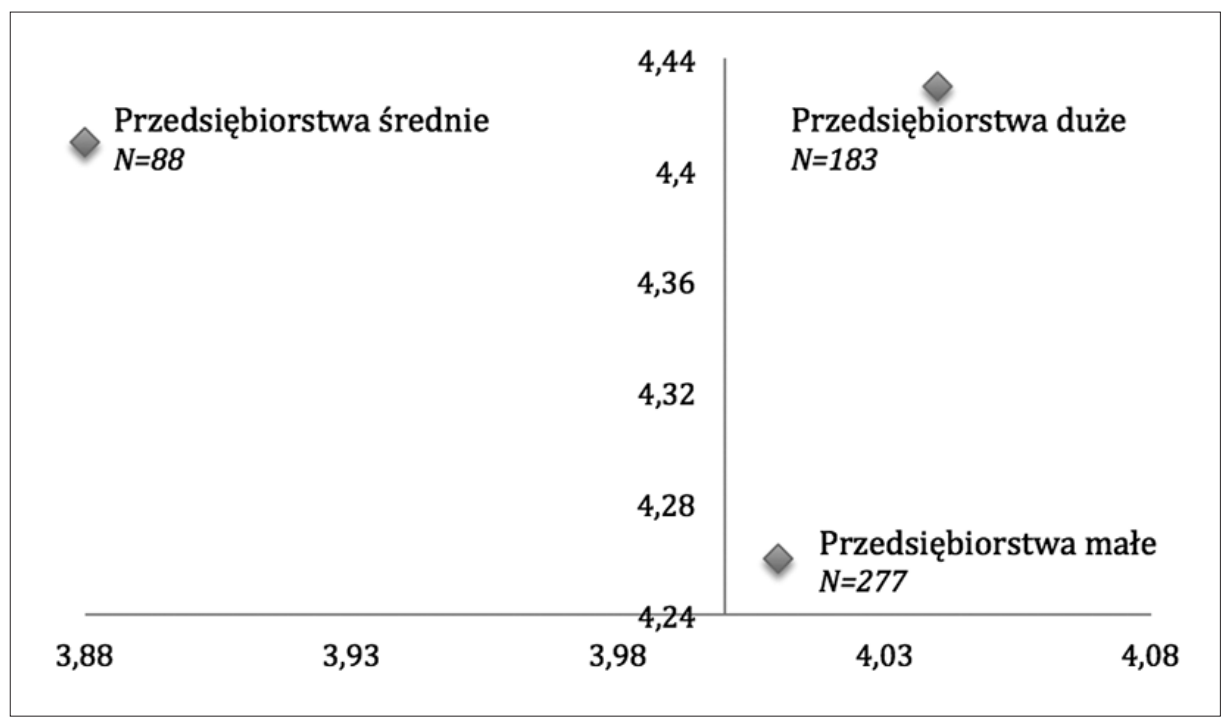

Rysunek 5. Wymiary przedsiębiorczej odnowy a wielkość przedsiębiorstwa

Źródło: opracowanie własne.

wszystkich organizacjach wyniosła 4,12, starannego planowania zaś 4,44. Staranność i zdyscyplinowanie nad eksperymentowaniem w przygotowywaniu nowych przedsięwzięć przeważa $\mathrm{w}$ największym stopniu $\mathrm{w}$ działalności finansowej oraz w usługach ubezpieczeniowych. Uzyskana pozycja analityka wynika przede wszystkim z charakteru tej branży. Okazuje się, że procesy odnowy przedsiębiorczej są najszybciej i najpełniej wprowadzane w sektorze handlu hurtowego i detalicznego. Zmiana oferty i wprowadzanie nowych towarów do obrotu nie wiąże się tu bowiem z pracochłonnym rozwojem nowych produktów. Z kolei przetwórstwo przemysłowe, choć mieści się w prawej górnej ćwiartce, charakteryzuje się niskim natężeniem przedsiębiorczej odnowy. Budownictwo i usługi charakteryzują się podobnym poziomem eksperymentowania i poszukiwania nowych szans w otoczeniu, choć - podobnie jak w odniesieniu do kryterium wieku - spontaniczne poszukiwanie szans zostało ocenione na poziomie umiarkowanym.

Jeśli chodzi o różnice w natężeniu wymiarów przedsiębiorczej odnowy ze względu na wielkość organizacji, dane te przedstawia fragment macierzy na rys. 5. Ponownie eksperymentowanie w odkrywaniu szans zostało, średnio rzecz biorąc, ocenione niżej $(4,0)$ niż zdyscyplinowane i staranne przygotowywanie nowych biznesów $(4,34)$.

Z przedstawionych analiz wynika, że przedsiębiorstwa średniej wielkości charakteryzują się niższym poziomem eksperymentowania w poszukiwaniu i odkrywaniu szans w otoczeniu. Z kolei firmy małe uzyskały niewysokie oceny eksperymentowania i staranności powyżej mediany, dlatego odnowa przedsiębiorcza w ich przypadku ma niskie natężenie. Przedsiębiorstwa dużez kolei przedkładają staranneanalizy i przygotowanie nowych biznesów nad spontaniczne wprowadzanie nowatorskich działań.

\section{Podsumowanie}

Celem niniejszego artykułu było przybliżenie istoty przedsiębiorczości organizacyjnej jako czynnika inicjującego procesy odnowy w organizacjach. Przedsiębiorczość, poprzez skupienie uwagi na poszukiwaniu i odkrywaniu szans w otoczeniu, powoduje, że organizacje bądź dostosowują się do swoich konkurentów, bądź stają się pionierami i wyprzedzają konkurencję. Każdorazowo wymaga to zmiany działalności, portfela produktów, strategii czy modelu biznesu.

Charakter odnowy zależy od sposobu odkrywania szans i organizacyjnych możliwości ich wdrożenia. Szanse przełomowe, burzące stan równowagi, stanowią podstawę całkowitej odnowy, odkrywanie zaś i naśladowanie konkurencji mają charakter dostosowawczy. Niedawno zaprezentowano interesującą poznawczo koncepcję, która rzuca pewne światło na identyfikację charakteru odnowy $\mathrm{w}$ organizacjach. Zgodnie $\mathrm{z}$ nią przedsiębiorczość organizacyjna opiera się na dwóch przeplatających się procesach: (a) oddolnego, spontanicznego eksperymentowania, związanego z odkrywaniem i podejmowaniem szans bez względu na racjonalność ekonomiczną i wykonalność inicjatyw, (b) skrupulatnego, starannego i opartego na twardych danych planowania nowych przedsięwzięć z oceną merytoryczności, ekonomiczności i wykonalności pojawiających się inicjatyw. Zestawienie tych dwóch wymiarów w różnych natężeniach tworzy propozycję struktury nośnej, pomocnej $\mathrm{w}$ określaniu typu odnowy związanej z odkrywaniem i wdrażaniem szans przez organizacje.

Badania przeprowadzone na próbie sześciuset sześciu organizacji w Polsce wykazały, że wśród badanych organizacji nie ma firm znajdujących się w stagnacji czy nieefektywnej antycypacji. Organizacje najstarsze, te z sektora działalności finansowej, a także średnie, uzyskały oceny, które plasują je w pozycji adaptacji do innych firm w sektorze i do otoczenia. 
Wyraźna większość badanych organizacji znajduje się w polu odnowy przedsiębiorczej, łącząc eksperymentowanie ze starannym planowaniem. Natężenie tych wymiarów jest jednak umiarkowane.

Należy jednak wskazać na ograniczenia przeprowadzonych analiz, związane $\mathrm{z}$ zaproponowanymi koncepcyjnymi wymiarami na macierzy, zastosowaną techniką badawczą, metodą badawczą i próbą badawczą. Po pierwsze, zaproponowana macierz wraz z jej wymiarami opiera się na wybranej koncepcji teoretycznej. Można wyobrazić sobie inną konfigurację wymiarów, a także inne normatywne rozwiązania w każdym z pól. Po drugie, użycie kwestionariusza ankiety związane jest z uzyskaniem subiektywnych wskazań dotyczących oceny danego zjawiska. Po trzecie, wypełnianie ankiet przez respondentów niesie zagrożenie bezrefleksyjnego zakreślania ocen przedstawianych stwierdzeń. Wreszcie badania zawęziły pole zainteresowania do przedsiębiorstw funkcjonujących w województwie śląskim, co może nie dawać pełnego obrazu przedsiębiorczej odnowy w organizacjach. Mimo pewnych ograniczeń, przedstawiony został jednak pewien obraz procesów związanych $\mathrm{z}$ podejmowaniem szans $\mathrm{w}$ badanych organizacjach, co może stanowić podstawę do dalszych, przyszłych analiz.

\section{Literatura}

Banaszyk P., Cyfert Sz., 2007, Strategiczna odnowa przedsiębiorstw, Difin, Warszawa.

Bilton C., Cummings S., 2010, Creative Strategy. Reconnecting business and innovation, John Wiley and Sons, Chichester.

Bełz G., 2012, Potencjał dostosowawczy w procesach odnowy przedsiębiorstw, Przegląd Organizacji, nr 11, s. 19-22.

Bratnicka K., Dyduch W., 2014, Strategiczna przedsiębiorczość: Koncepcja i pomiar, Prace Naukowe WWSZIP, nr 27(2), s. 167-192.

Bratnicki M., 2008, Konfiguracyjne ujęcie przedsiębiorczości organizacyjnej, Ekonomika i Organizacja Przedsiębiorstwa, nr 6, s. 17-22.

Burgelman R.A., 1984, Designs for corporate entrepreneurship, California Management Review, vol. 26, s. 154-166.

Cyfert Sz., 2012, Systemowy model organizacji: perspektywa procesów odnowy organizacyjnej, Prace Naukowe Uniwersytetu Ekonomicznego we Wrocławiu, nr 276, s. 123-129.

Cyfert Sz., Bełz G., Wawrzynek Ł., 2014, Wpływ burzliwości otoczenia na efektywność procesów odnowy organizacyjnej, Organizacja i Kierowanie, nr 1A (159), s. 15-26.

Dess G.G., Ireland R.D., Zahra S.A., Floyd S.W., Janney J.J., Lane P.J., 2003, Emerging issues in corporate entrepreneurship, Journal of Management, vol. 29(3), s. 351-378.
Dougherty D., 1992, A practice-centered model of organizational renewal through product innovation, Strategic Management Journal, vol. 13, s. 77-92.

Dyduch W., 2013, Twórcza strategia organizacji, Wydawnictwo Uniwersytetu Ekonomicznego w Katowicach, Katowice.

Ferreira J., 2002, Corporate Entrepreneurship: A Strategic and Structural Perspective, ICSB $47^{\text {th }}$ World Conference, Puerto Rico.

Gabryś B.J., 2014, Narracja jako metoda badania strategicznej odnowy organizacji na przykładzie Tauron S.A., Marketing i Rynek, nr 5, s. 346-351.

Guth W., Ginsberg A., 1990, Guest editors' introduction: Corporate entrepreneurship, Strategic Management Journal, no 11, s. 297-308.

Hitt M.A., Ireland R.D., Sirmon G., Trahms Ch.A., 2011, Strategic entrepreneurship: Creating value for individuals, organizations and society, Academy of Management Perspectives, no 5, s. 57-75.

Ireland R.D., Covin J.G., Kuratko D.F., 2009, Conceptualizing corporate entrepreneurship strategy, Entrepreneurship Theory and Practice, vol. 33, no 1, s. 19-46.

Krzakiewicz K., Cyfert Sz., Kraśnik J., 2006, Zmiany w systemach planowania i organizowania polskich przedsiębiorstw, Przegląd Organizacji, 2006, nr 2, s. 21-23.

Kuratko D., Montagno R.V., Hornsby J.S., 1990, Developing an intrapreneurial assessment instrument for effective corporate entrepreneurial environment, Strategic Management Journal, no 11, s. 49-58.

Miller D., 1983, The correlates of entrepreneurship in three types of firms, Management Science, vol. 29, no 7, s. 770-791.

Miller D., Friesen P.H., 1982, Innovation in Conservative and Entrepreneurial Firms: Two Models of Strategic Management, Strategic Management Journal, no 3, s. 1-25.

Sathe V., 1989, Fostering entrepreneurship in the large, diversified firm, Organizational Dynamics, vol. 18, no 1, s. 20-32.

Shane S., Venkataraman S., 2000, The promise of entrepreneurship as a field of research, Academy of Management Review, vol. 25, no 1, s. 217-226.

Stevenson H.H., Jarillo J.C., 1990, A paradigm of entrepreneurship: Entrepreneurial management, Strategic Management Journal, vol. 11, s. 17-27.

Stopford J.M., Baden-Fuller C.W.F., 1994, Creating corporate entrepreneurship, Strategic Management Journal, vol. 15, s. 521-536.

Zahra S.A., 1993, Environment, corporate entrepreneurship, and financial performance: A taxonomic approach, Journal of Business Venturing, vol. 8, no 4, s. 319-340.

Zahra S.A., 1991, Predictors and financial outcomes of corporate entrepreneurship: An explorative study, Journal of Business Venturing, no 6, s. 259-285.

Zahra S.A., 1993, A conceptual model of entrepreneurship as firm behaviour. A critique and extension, Entrepreneurship Theory and Practice, vol. 16, s. 5-21. 